\title{
Pemenuhan Hak-Hak terhadap Pembinaan Narapidana di Kota Ternate
}

\author{
Dewi Suyatni \\ Fakultas Hukum Universitas Khairun.E-mail: yatnisay@gmail.com
}

\author{
Muh Mufti M Djafar \\ Fakultas Hukum Universitas Khairun.E-mail: m.mufti@unkhair.ac.id
}

\begin{abstract}
:
Correctional Institutions in Indonesia are still in the public spotlight because they often experience various problems that do not go away, ranging from overcapacity and the practice of extortion. Therefore, to find out the guiding model for prisoners, a research is conducted so that it is not free from a dynamic that aims to provide prisoners with provisions in facing life after serving a sentence (free), so that when they leave prison, they are ready to mingle with the community. This research was conducted at the Penitentiary Class II A Ternate, Jl Pengayoman No.1 Jambula. Fulfillment of Rights is a business that must be fulfilled because it is a necessity, these rights are not only obtained by people who are not ensnared by the law but someone who violates the law, someone who is being processed in court even someone who is serving a sentence in a prison institution also has protected rights and must be fulfilled. In its implementation, a prisoner is also a human being and a prisoner receives guidance or special service because inmates also have birth rights that cannot be opposed by anyone. In the pattern and method of fostering prisoners, there are 5 rights raised, namely the Right to Registration and Placement, the Right to Appropriate Food and Drink, the Right to Health, the Right to Connect with Outside Parties, and the Right to Social Reintegration.
\end{abstract}

Keywords: Fulfillment of Rights, Guidance for Prisoners

\section{PENDAHULUAN}

Lembaga Pemasyarakatan di Indonesia masih menjadi sorotan publik karena kerap mengalami berbagai masalah yang tidak kunjung selesai, mulai dari over kapasitas dan terjadinya praktik pungutan liar. Apabila melihat cita-cita dalam mengembangkan kehidupan berbangsa dan bernegara, maka dapat dikatakan bahwa tujuan pembangunan nasional setidak-tidaknya adalah untuk:

1. menjamin terwujudnya negara berdasar atas hukum (rechstaats) dan perlindungan hak asasi manusia;

2. menjamin terwujudnya kehidupan kenegaraan yang demokratis;

3. mempercepat terwujudnya keadilan sosial bagi seluruh rakyat indonesia, dan

4. menjamin terwujudnya pemerintahan yang layak (good governance) (Yusril Ihza mahendra.2002:11). ${ }^{1}$

\footnotetext{
${ }^{1}$ Yusril Izha Mahendra, Gagasan dan Pemikiran Tentang Pembaharuan Hukum Nasional, PT Deltacitra Grafindo, Jakarta, 2002,11
} 
Keempat tujuan diatas merupakan tujuan yang sangat fundamental yang harus diperhatikan dalam pembangunan hukum nasional. Untuk mendukung berbagai upaya yang dilakukan kearah itu, pembangunan hukum seyogianya pada masa-masa mendatang perlu dititikberatkan pada langkah-langkah strategis yang mencakup seluruh elemen sistem hukum. Lawrence W Friedman memberikan konsep sistem hukum dalam arti luas (Lawrence W Friedman. 1984: 1-8.) '2meliputi tiga elemen sistem hukum, yaitu elemen struktural (Structure), substansi (subtance), budaya hukum (legal culture).

Prinsip-prinsip negara berdasar hukum, demokrasi dan prinsip-prinsip penting lainnya, harus acuan nilai dalam setiap langkah strategis pembangunan hukum (legislation planing), proses pembuatan hukum (law making process) sampai pada penegakan hokum (law enforcement) dan kesadaran hukum (law awareness) (Muladi.2002:231) ${ }^{3}$. Kondisi umum di bidang hukum saat ini menunjukan perkembangan yang kontroversial. Di satu pihak produk materi hukum, pembinaan aparatur negara, sarana dan prasarana cukup menunjukan peningkatan; namun dilain pihak perkembangan tersebut tidak diimbangi secara memadai dengan peningkatan itegritas moral dan profesionalisme aparat hukum, mutu pelayanan serta adanya kepastian hukum dan keadilan. Persoalan-persoalan yang menyangkut kinerja sistem peradilan, lembaga-lembaga penegak hukum, sumberdaya manusia di bidang hukum, organisasi profesi dan lain-lain.

Sebelum Undang-Undang No. 12 tahun 1995 tentang pemasyarakatan diberlakukan di Indonesia, dasar hukum penyelenggaraan pembinaan narapidana adalah Reglemen penjara (Gestichen Reglement 1917 No. 708), yang menempatkan posisi narapidana sebagai objek yang sama sekali tidak mempunyai tujuan pembinaan, semata mata penjeraan (pembalasan). Diberlakukannya Undang-Undang No. 12 Tahun 1995 sebagai wujud pembaharuan di bidang hukum pidana, telah membawa suasana baru dalam penegakan hukum pidana, tetapi dalam praktik hukum sehari-hari menghadapi problem, yaitu bagaimana menumbuhkan atau meningkatkan kepercayaan masyarakat terhadap hukum dan sistem peradilan pidana sehingga masyarakat (narapidana) sebagai pencari keadilan, merasa terayomi, dan merasa aman dan tentram. Perlindungan hukum terhadap narapidana diperlukan agar narapidana memperoleh hak dasarnya yaitu perlakuan secara adil. Dalam sejarah pelaksanaan sistem peradilan pidana, narapidana diposisikan sebagai objek dan memperoleh perlakuan yang tidak adil oleh petugas dalam lingkaran system peradilan pidana.

Dari beberapa hal yang telah calon peneliti kemukakan di atas, menggambarkan bahwa hal tersebut sebagai konsekwensi logis dari perubahan tata perlakuan terhadap narapidana dari sistem kepenjaraan menjadi sistem pemasyarakatan. Namun sampai saat ini peranan lembaga pemasyarakatan senantiasa dihadapkan kepada problema dilematis yang belum terselesaikan sampai saat ini. Berbagai hambatan yang dihadapi belum terdapat kejelasan antisipasinya. Fenomena tersebut jika tidak segera dicari agar permasalahannya akan mengakibatkan gagalnya implementasi sistem pemasyarakatann sebagai salah satu sub sistem Hukum Nasional dibidang prevention of crime and the treatment for the offenders.

\footnotetext{
${ }^{2}$ Lawrence M. Friedman, American law: An Invaluable guide to the many faces of the law, and how it effects our daily lives, New York: W.W. Nonton \& Company, 1984,1-8

${ }^{3}$ Muliadi, Kapita Selekta Sistem Peradilan Pidana, Badan Penerbit UNDIP, Semarang, 1995, 231
} 


\section{TINJAUAN PUSTAKA}

\section{A. Konsep Umum Narapidana}

Secara bahasa dalam Kamus Besar Bahasa Indonesia (KBBI) arti darinarapidana adalah orang yang sedang menjalani hukuman karena telah melakukan suatu tindak pidana, ${ }^{4}$ sedangkan menurut kamus induk istilah ilmiah menyatakan bahwa narapidana adalah orang hukuman atau orang buian. ${ }^{5}$ Dalam Kitab Undang-Undang Hukum Acara Pidana (KUHAP) tercantum pada Pasal 1 angka 32, terpidana adalah seseorang yang dipidana berdasarkan putusan pengadilan yang telah memperoleh kekuatan hokum tetap.

Menurut Pasal 1 ayat (7) Undang-Undang Nomor 12 Tahun 1995 tentang Pemasyarakatan menjelaskan bahwa narapidana adalah terpidana yang sedang menjalani pidana hilang kemerdekaan di Lembaga Pemasyarakatan, menurut Pasal 1 ayat (6) Undang-Undang Nomor 12 Tahun 1995 Tentang Pemasyarakatan, terpidana adalah seseorang yang dipidana berdasarkan putusan pengadilan yang telah memperoleh kekuatan hukum tetap. Pernyataan diatas dapat disimpulkan bahwa narapidana adalah seseorang atau terpidana yang sebagian kemerdekaannya hilang sementara dan sedang menjalani suatu hukuman di Lembaga Pemasyarakatan. Sebelum istilah narapidana digunakan, yang lazim dipakai adalah orang penjara atau orang hukuman. Dalam Pasal 4 ayat (1) Gestichtenreglement (Reglemen Penjara) Stbl. 1917 No. 708 disebutkan bahwa orang terpenjara adalah Orang hukuman yang menjalani hukuman penjara (Gevengenis Straff) atau suatu status/keadaan dimana orang yang bersangkutan berada dalam keadaan Gevangen atau tertangkap Orang yang ditahan buat sementara, Orang di sel, Sekalian orang-orang yang tidak menjalani hukuman orang-orang hilang kemerdekaan (Vrijheidsstraaf) akan tetapi dimasukkan ke penjara dengan sah.

\section{B. Hak Asasi Manusia}

Dalam Undang-Undang Nomor 39 Tahun 1999 tentang Hak AsasiManusia, tercantum dalam Pasal 1 disebutkan bahwa:

"Hak Asasi Manusia (HAM) adalah seperangkat hak yang melekat padahakikat dan keberadaan manusia sebagai makhluk Tuhan Yang Maha Esadan merupakan anugerahNya yang wajib dihormati, dijunjung tinggi,dan dilindungi oleh negara, hukum, pemerintah dan setiap orang demikehormatan serta perlindunganharkat dan martabat manusia".

John Locke menyatakan bahwa hak asasi manusia adalah hak-hak yangdiberikan langsung oleh Tuhan Yang Maha Pencipta sebagai hak yang kodrati. Oleh karenanya, tidak ada kekuasaan apapun di dunia yang dapat mencabutnya. Hak ini sifatnya sangat mendasar (fundamental) bagi hidup dan kehidupan manusia dan merupakan hak kodrati yang tidak bisa terlepas daridan dalam kehidupan manusia. Hakikat dari penghormatan dan perlindungan terhadap HAM ialah menjaga keselamatan eksistensi manusia secara utuhmelalui aksi keseimbangan yaitu keseimbangan antara hak dan kewajiban, sertakeseimbangan antara kepentingan perseorangan dan kepentingan

umum. Konsep HAM memiliki dua pengertian dasar :

1. Hak yang tidak dapat dipisahkan dan dicabut, yakni hak moral yangberasal dari kemanusiaan setiap insan dan bertujuan untuk menjaminmarrtabat setiap manusia.

\footnotetext{
${ }^{4}$ Kamus Besar Bahasa Indonesia.Narapidana.https://kbbi.web.id. Diakses pada 22Desember 2017.

${ }^{5}$ Dahlan, M.Y. Al-Barry, 2003.Kamus Induk Istilah Ilmiah Seri Intelectual.Surabaya.Target Press. Hlm 53
} 
2. Hak menurut hukum, yang dibuat sesuai dengan proses pembuatan hukumdari masyarakat itu sendiri,baik secara nasional maupun internasional. Dasar dari hak ini adalah persetujuan orang yang diperintah, yaitupersetujuan dari para warga, yang tunduk pada pada hak-hak itu dan tidak hanya tertib alamiah, yang merupakan dasar dari arti yang pertama tersebut di atas.

\section{Bahan Bacaan dan Siaran media Massa}

Berdasarkan isi dari Pasal 14 ayat (1) huruf f Undang-Undang Nomor 12Tahun 1995 tentang Pemasyarakatan,Narapidana berhak mendapatkan bahanbacaan dan mengikuti siaran media massa lainnya yang tidak larangan.Sedangkan menurut Peraturan Pemerintah Republik Indonesia Nomor 32Tahun 1999 tentang Syarat dan Tata Cara Pelaksanaan Hak Warga Binaan Pemasyarakatan yang tercantum pada Pasal 27 ayat (1) yakni setiap LAPAS menyediakan bahan bacaan, media massa yang berupa media cetak dan mediaelektronik.

\section{Bahan Bacaan}

Dalam Kamus Besar Bahasa Indonesia, bahan diartikan sebagai segala sesuatu yang dapat dipakai atau diperlukan untuk suatu tujuan tertentu, sedangkan arti dari bacaan sendiri adalah buku dan sebagainya. Bahan bacaan digunakan hanya untuk memperkaya pengetahuan pembaca dalam menambah pengetahuan dari segi rekreasi intelektual serta khazanah pengetahuan lainnya yang mendukung Dalam Kamus Besar Bahasa Indonesia, bahan diartikan sebagaisegala sesuatu yang dapat dipakai atau diperlukan untuk suatu tujuan tertentu, sedangkan arti dari bacaan sendiri adalah buku dan sebagainya. Bahan bacaan digunakan hanya untuk memperkaya pengetahuan pembaca dalam menambah pengetahuan dari segi rekreasi intelektual serta khazanah pengetahuan ainnya yang mendukung ${ }^{6}$. Dalam Pasal 1 ayat (4) Peraturan Menteri Dalam Negeri danOtonomi Daerah Nomor 3 Tahun 2001 tentang Perpustakaan Desa/Kelurahan

"Mendefinisikan bahan bacaan adalah semua media cetak yang disediakan bagi masyarakat dalam bentuk buku, majalah, tabloit,brosur, surat kabar, lelaflet dan bahan cetakan lainnya yang bersifat informatif yang dapat dibaca, dipelajari dan memberi manfaat bagi kehidupan masyarakat.

Materi hak narapidana yang terdapat pada pedoman PBB mengenai standar peraturan untuk perlakuan narapidana yang menjalani hukuman (Standard Minimum Rules for the Treatment Prisoner) 31 Juli 1957 menyebutkan bahwa narapidana berhak untuk mendapatkan bahan bacaan berupa buku-buku yang bersifat mendidik. ${ }^{7}$

\section{Siaran Media Massa}

Media adalah sebuah sarana komunikasi tempat dimana orang mengirimkan dan menerima informasi. Sementara itu, yang dimaksud dengan massa adalah sarana dan saluran resmi sebagai alat komunikasi untuk menyebarkan berita dan pesan kepada masyarakat luas. Dengan demikian, media massa merujuk pada suatu sarana alat komunikasi untuk menerima informasi dan menyebarkan berita atau pesan untuk masyarakatluas. ${ }^{8}$ Istilah media massa seringkali merujuk pada mediamainstream yang dapat dibedakan dari berbagai media alternatif berdasarkan isi media dansudut pandang. Media alternatif dapat disebut sebagai media massa manakala menggunakan teknologi yang tepat yang dapat

\footnotetext{
${ }^{6}$ Perpustakaan Fakultas Psikologi Universitas Diponegoro.Bahan Bacaan.http://lib.psikologi.undip.ac.id. Diakses pada 4 Januari 2018

${ }^{7}$ Op.Cit. Wahdaningsi. Hlm. 19.

${ }^{8}$ Kamus Besar Bahasa Indonesia.Media Massa.https://kbbi.web.id. Diakses pada 30Desember 2017
} 
menjangkau khalayak secara luas walaupun tidak sebesar media mainstream. Beriku tadalah beberapa pengertian media massa menurut ahli, yaitu ${ }^{9}$

a. Dictionary of Media and Communications, media massa adalah media (radio, televisi, buku, majalah, surat kabar, periodik, laman atau websites) yang menjangkau khalayak luas.

b. Roger D. Wimmer dan Joseph R. Dominick, media massa merujuk pada berbagai bentuk komunikasi yang secara simultan menjangkau sejumlah besar orang, termasuk namun tidak terbatas pada radio, TV, surat kabar, majalah,billboards,film, rekaman, buku, dan Internet.

c. Nickolas Luhmann, media massa adalah institusi yang menggunakan teknologi penggandaan untuk menyebarkan komunikasi. Luhmann menekankan pada adanya aspek-aspek dalam media massa, yaitu aspek efisien dan aspek ekonomis. Media adalah segalanya yangdapat menyatukan jumlah produk secara luas kepada kelompok sasaran yang tidak ditentukan.

Media cetak merupakan media yang bersifat statis danmengutamakan pesan-pesan visual. Media ini terdiri dari lembaran kertasdengan sejumlah kata, gambar, sejumlah foto dengan tata warna danhalaman. Media cetak merupakan dokumen atas segala yang dikatakanorang lain, rekaman peristiwa yang ditangkap oleh jurnalis dan diubah dalam bentuk kata-kata, gambar, foto dan semacamnya untuk dijadikansebuah berita. Media massa cetak secara rinci meliputi :

1. Koran atau suratkabar (ukuran kertas broadsheet atau $1 / 2$ plano)

2. Tabloid (1/2 broadsheet)

3. Majalah (1/2 tabloid atau kertas ukuran folio/kwarto)

4. Buku (1/2 majalah)

5. Newsletter (folio/kwarto, jumlah halaman lazimnya 4-8)

6. Buletin (1/2 majalah, jumlah halaman lazimnya 4-8).

\section{Lembaga Pemasyarakatan}

\section{Pengertian Lembaga Pemasyarakatan}

Menurut Kamus Besar Bahasa Indonesia pengertian lembaga pemasyarakatan adalah sebagai berikut ${ }^{10}$. Lembaga adalah organisasi atau badan yang melakukan suatu penyelidikan atau usaha. Pemasyarakatan adalah nama yang mencakup semua kegiatan yang keseluruhannya dibawah pimpinan dan pemilikan Departemen Hukumdan HAM, yang berkaitan dengan pertolongan bantuan atau tutuntan kepada hukuman/bekas tahanan, termasuk bekas terdakwa atau yang dalam tindak pidana diajukan kedepan pengadilan dan dinyatakan ikut terlibat, untuk kembali kemasyarakat. Tercantum dalam Undang-Undang Nomor12 Tahun 1995 tentang Pemasyarakatan, Pasal 1 ayat (1) dijelaskan bahwa Pemasyarakatan adalah kegiatan untuk melakukan pembinaan Warga Binaan Pemasyarakatan berdasarkan sistem, kelembagaan, dan cara pembinaan yang merupakan bagian akhir dari system pemidanaan dalam tata peradilan pidana. Sedangkan dalam Pasal

\footnotetext{
${ }^{9}$ Pakar Komunikasi.Karakteristik Media Massa dan Fungsinya.https://pakarkomunikasi.com. Diakses pada 30

Desember 2017

${ }^{10}$ Afandi Haris Raharjo, 2014.Pemenuhan Hak Narapidana Untuk MendapatkanPendidikan Di Lembaga Pemasyarakatan
} 
1 ayat (3) disebutkan Lembaga Pemasyarakatan adalah tempat untuk melaksanakan pembinaan Narapidana dan Anak Didik Pemasyarakatan.

\section{Sejarah Pemasyarakatan}

Sejak bangsa Indonesia memproklamasikan kemerdekaan 17 Agustus1945 yang itu tentu dalam upaya perbaikan terhadap pelanggar hukum baik yang berada dalam penahanan sementara maupun yang sedang menjalani pidana, tahun-tahun penting yang menjadi tonggak sejarah dunia dalam upaya perbaikan tersebut. Pertama, tahun 1933 ketika The International Penal dan Penitentary Commision (IPPC), sebuah komisi Internasional mengenai pidana dan pelaksanaan pidana itu pada tahap merencanakan. Kedua, tahun 1934 dimana IPPC mulai mengajukan untuk disetujui oleh The Asembly of TheLeaque of Nation, yaitu rapat umum organisasi bangsabangsa. Ketiga,tahun 1955 naskah IPPC yang diperbaiki oleh sekretariat PBB disetujui oleh Kongres PBB, yang dijadikan Standart Minimum Rules (SMR) dalam pembinaan napi. Keempat,tepatnya tanggal 31 Juli 1957 Dewan Ekonomidan Sosial PBB (Resolusi No. 663C XXIV) menyetujui dan menganjurkan pada pemerintahan dari setiap negara untuk menerima dan menerapkannya. ${ }^{11}$

Upaya perbaikan di Indonesia juga tidak berhenti disitu saja, diawalipada 5 Juli 1963 di Istana Negara RI ketika Sahardjo, SH, Menteri Kehakiman mendapat anugerah gelar Doktor Honoris Causa bidang hokum dengan pidatonya "Pohon Beringin Pengayoman" dinyatakan bahwa tujuan dari pidana penjara adalah "Pemasyarakatan" dan juga mengemukakan konsep tentang hukum nasional, yang digambarkan sebuah "Pohon Beringin" untuk melambangkan "Tugas hukum ialah memberi pengayomanagar cita-cita luhur bangsa tercapai dan terpelihara. DR,Sahardjo, SH adalah seorang tokoh yang menancapkan tiang pancang perubahan dalam bidang pemasyarakatan. ${ }^{12}$

Struktur organisasi Lembaga Pemasyarakatan berdasarkan pada Surat Keputusan Menteri Kehakiman Rl No. M-01.-PR.07.03 Tahun 1985 dalam Pasal 4 ayat (1) diklasifikasikan dalam 3 klas yaitu:

1) Lembaga Pemasyarakatan (Lapas) Klas I

2) Lembaga Pemasyarakatan (Lapas) Klas II A

3) Lembaga Pemasyarakatan (Lapas) Klas II B Klasifikasi tersebut didasarkan atas kapasitas, tempat kedudukan dan kegiatan kerja. Lembaga Pemasyarakatan menurut Departemen Hukum dan HAM Rl adalah unit pelaksana teknis (UPT) pemasyarakatan yang menampung, merawat dan membina narapidana.

\section{METODE PENELITIAN}

Untuk mendapatkan data dan informasi yang dibutuhkan dalam penelitian ini, maka lokasi penelitian dilakukan di Lembaga Pemasyarakatan Kelas II A Ternate , Jl Pengayoman No.1 Jambula Kota Ternate.

Untuk menjawab permasalahan yang telah dirumuskan dalam penelitian ini maka peneliti akan menggunakan tipe penelitian deskriptif analisis dengan melakukan pendekatan secara kualitatif. Oleh karena didalam penelitian ini yang menjadi focus kajian adalah pola dan cara pembinaan narapidana di Lembaga Pemasyarakatan. Sedangkan pendekatan dalam penelitian ini ialah menggunakan pendekatan konseptual (conceptual approach) dan pendekatan instrument hukum (statute approach).

\footnotetext{
${ }^{11}$ Akhmad Sekhu.Sejarah dari Lapas.https://www.kompasiana.com. Diakses pada 1Januari 2018

${ }^{12}$ Op.Cit.Andi Soraya Tenrisoji. Hlm. 32
} 
Teknik pengumpulan data yang calon peniliti gunakan dalam penelitian ini melalui studi kepustakaan, studi lapangan dan studi dokumentasi. Ke tiga studi pengumpulan data tersebut digolongkan menjadi dua bagian yakni data primer dan data sekunder, data primer diperoleh melalui studi lapangan sedangkan data sekunder diperoleh melalui studi kepustakaan dan studi dokumentasi.

Adapun prosedur penelitian dilakukan dengan tahapan antara lain sebagai berikut:

1. Persiapan dan penyusunan instrument penelitian;

2. Identifikasi permasalahan;

3. Pengumpulan dan analisis data;

4. Penyusunan hasil penelitian; dan

5. Menindaklanjuti rencana output/luaran penelitian.

\section{PEMBAHASAN}

\section{A. Pola Dan Cara Pembinaan Narapidana Di Lembaga Pemasyarakatan Kelas II Jambula Di Kota Ternate}

Pemenuhan Hak merupakan usaha yang harus terpenuhi karna itu sesuatu kebutuhan, hak tersebut tersebut tidak hanya diperoleh oleh orang-orang yang tidak terjerat hukum melainkan seseorang yang melanggar hukum, seseorang yang sedang diproses dalam pengadilan bahkan seseorang yang menjalani hukuman dilembaga pemasyarakatan juga mempunyai Hak yang dilindungi dan harus terpenuhi. Dalam implementasinya Narapidana juga adalah seorang manusai dan narapidana mendapatkan pembinaan atau pelayanan khusus karna narapidana juga sejak lahir mempunyai hak yang tidak bisa ditentang oleh siapapun.

a. Hak pendaftaran dan Penempatan

Hak Pendaftaran dan penempatan adalah tahap awal yang dilalui bagi narapidana ketika berada didalam lapas tersebut, akan tetapi adapun pertanyaan yang digunakan untuk mengetahui apakah pemenuhan hak tersebut sudah terpenuhi antaralain : periksaan identitas, difoto, sidik jari, pengeladahan oleh petugas, penjelasan mengenai hak dan kewajiban, larangan dan sanksi, pengenalan blok. Adapun pertanyaan yang peneliti lakukan kepada petugas lapas yaitu :

$\checkmark$ P.1 Apakah pada saat pertama kali masuk ke Lapas narapidana diperiksa identitas, difoto dan diambil sidik jari oleh petugas Lapas?

$\checkmark$ P.1 Apakah narapidana mengalami pengeledahan oleh petugas ?

$\checkmark$ P.1 Apakah pada saat pertama kali masuk ke Lapas narapidana diberikan penjelasan mengenai hak dan kewajiban, larangan dan sanksi ?

$\checkmark$ P.1 Apakah pernah dipertanyakan di blok masa pengenalan lingkungan ?

Dari tabel diatas menjelaskan bahwa pada pemenuhan hak pendaftaran dan penempatan di Lapas kelas II Jambula Ternate dikategorikan baik dikarnakan pemenuhan tersebut seluruh narapidana mendapatkan hak tersebut didalam lapas. 


\begin{tabular}{|c|l|c|}
\hline NO & \multicolumn{1}{|c|}{ INDIKATOR PERTANYAAN } & YA/TIDAK \\
\hline 1 & $\begin{array}{l}\text { Apakah pada saat pertama kali masuk ke Lapas narapidana } \\
\text { diperiksa identitas, difoto dan diambil sidik jari oleh petugas Lapas }\end{array}$ & YA \\
\hline 2 & Apakah narapidana mengalami pengeledahan oeleh petugas & YA \\
\hline 3 & $\begin{array}{l}\text { Apakah pada saat pertama kali masuk ke Lapas narapidana } \\
\text { diberikan penjelasan mengenai hak dan kewajiban, larangan dan } \\
\text { sanksi }\end{array}$ & YA \\
\hline 4 & Apakah pernah dipertanyakan di blok masa pengenalan lingkungan & YA \\
\hline
\end{tabular}

b. Hak Atas Makanan dan Minuman Yang Layak

Ha katas makanan dan minuman adalah kebutuhan pokok yang harus didapatkan setiap narapidana didalam Lapas, karna apabila tidak dipenuhi hak tersebut setiap narapidana akan mengalami sakit dan akan memicu konflik di dalam Lapas sehingga makanan harus disediakan dengan baik dan layak untuk dimakan setiap narapidana. Pertanyaan dilakukan setiap narapidana meliputi: disediakan peralatan makan dan inuman yang layak, disediakan makanan tiga kali sehari tepat waktu, makanan disajikan layak untuk dimakan, menu yang bervariasi, serta air minum tersedia setiap saat dan bisa didapatkan cuma-cuma. Adapun pertanyaan yang dilakukan ke petugas lapas yaitu :

$\checkmark$ B.1: Apakah disediakan peralatan makan dan minum yang layak ?

$\checkmark$ B.2: Apakah disediakan makanan tiga kali sehari secara tepat waktu ?

$\checkmark$ B.3: Apakah makanan yang disajikan layak untuk dimakan?

$\checkmark$ B.4: Apakah menu yang disajikan bervariasi ?

$\checkmark$ B.5: Apakah air minum tersedia setiap saat dan bisa didapatkan cuma-cuma?

\begin{tabular}{|c|l|c|}
\hline NO & \multicolumn{1}{|c|}{ INDIKATOR PERTANYAAN } & YA/TIDAK \\
\hline 1 & $\begin{array}{l}\text { Apakah disediakan peralatan makan dan minum yang } \\
\text { layak }\end{array}$ & YA \\
\hline 2 & $\begin{array}{l}\text { Apakah disediakan makanan tiga kali sehari secara tepat } \\
\text { waktu }\end{array}$ & YA \\
\hline 3 & Apakah makanan yang disajikan layak untuk dimakan & YA \\
\hline 4 & Apakah menu yang disajikan bervariasi & YA \\
\hline 5 & $\begin{array}{l}\text { Apakah air minum tersedia setiap saat dan bisa } \\
\text { didapatkan cuma-cuma }\end{array}$ & YA \\
\hline
\end{tabular}

Dari table menjelaskan pada pemenuhan hak makanan dan minuman dikategorikan baik. Hal ini dibuktikan setiap narapidana didalam lapas mendapatkan makanan dan minuman yang layak untuk dikonsumsi. Sehingga narapidana tidak merasakan kelaparan didalam lapas tersebut. Hal tersebut tidak lepas dari kepedulian lapas untuk memenuhi hak tersebut. 
c. Hak Atas Kesehatan

Hak atas kesehatan merupakan pertanyaan yang menjadi perhatian khusus karna ini menyangkut kesehatan narapidana dan harus dilakukan secara rutin didalam lapas tersebut yang bertujuan menghindari narapidana mengalami berbagai penyakit dan narapidana seharusnya mempunyai kesadaran untuk memeriksa kesehatannya masing-masing karna keterbukaan setiap narapidana yang melakukan pengecekan kesehatan akan membantu petugas kesehatan untuk mengeceknya. Adapun pertanyaan yang dilakukan meliputi: pelayanan kesehatan umum oleh dokter, pemeriksaan rutin atau control kesehatan setiap hari ke blok, informasi pelayanan gigi informasi pelayanan kesehatan gigi oleh dokter gigi, informasi pelayanan konsultasi kejiwaan, serta pendampingan petugas tahanan yang stress. Adapun pertanyaan yang dilakukan kepada petugas lapas yaitu :

$\checkmark$ C.1 : Apakah ada pelayanan kesehatan umum oleh dokter?

$\checkmark$ C.2 : Apakah ada pemeriksaan rutin atau control kesehatan setiap hari ke blok ?

$\checkmark$ C.3 : Apakah ada informasi pelayanan kesehatan gigi oleh dokter gigi ?

$\checkmark$ C.4 : Apakah ada informasi pelayanan konsultasi kejiwaan?

$\checkmark$ C.5 : Apakah ada pendampingan petugas terhadap tahanan yang stress ?

\begin{tabular}{|c|l|c|}
\hline NO & \multicolumn{1}{|c|}{ INDIKATOR PERTANYAAN } & YA/TIDAK \\
\hline 1 & Apakah ada pelayanan kesehatan umum oleh dokter & YA \\
\hline 2 & $\begin{array}{l}\text { Apakah ada pemeriksaan rutin atau control kesehatan } \\
\text { setiap hari ke blok }\end{array}$ & TIDAK \\
\hline 3 & $\begin{array}{l}\text { Apakah ada informasi pelayanan kesehatan gigi oleh } \\
\text { dokter gigi }\end{array}$ & TIDAK \\
\hline 4 & Apakah ada informasi pelayanan konsultasi kejiwaan & TIDAK \\
\hline 5 & $\begin{array}{l}\text { Apakah ada pendampingan petugas terhadap tahanan } \\
\text { yang stress }\end{array}$ & TIDAK \\
\hline
\end{tabular}

Dari Tabel menjelaskan pada pemenuhan hak perawatan kesehatan pada pertanyaan C.2 sampai pertanyaan ke C.5 dikategorikan "Kurang". Karna kurangnya petugas khusus dalam pelayanan tersebut, hal ini dapat berdampak bagi petugas lapas tersebut, karna petugas tidak mengetahui narapidana manasaja yang kana mengalami gangguan kejiwaan atau stress. Sehingga bisa saja akan membahayakan setiap narapidana lain maupun petugas lapas.

d. Hak berhubungan dengan pihak luar

Berhubungan dengan pihak luar merupakan salah satu kebutuhan setiap narapidana, karna hal ini sangat dimanfaatkan narapidana untuk bertemu sanak saudaranya maupun orang terdekatnmya bahkan penasehat hukumnya sekalipun. Adapun pertanyaan yang diajukan meliputi : apakah lokasi lapas berdekatan dengan tempat tinggal narapidana, diperkenankan menerima kunjungan sesuai jadwal, dikenakan iuran untuk kunjungan, dibolehkan menerima kiriman dari orang kunjungan, serta dizinkan menerima pengacara/penasehat hukumnya. Adapun pertanyaan yang dilakukan ke petugas lapas yaitu:

$\checkmark$ D.1 : Apakah Lokasi lapas berdekatan dengan lokasi tempat tinggal narapidana ? 
$\checkmark$ D.2 : Apakah narapidana diperkenankan menerima kunjungan sesuai jadwal yang dizinkan?

$\checkmark$ D.3 : Apakah dikenakan Iuran untuk kunjungan ?

$\checkmark$ D.4 : Apakah narapidana dibolehkan menerima kiriman dari orang yang berkunjung ?

$\checkmark$ D.5 : Apakah narapidana dizinkan menerima kunjungan dari pengacara/penasehat hukum ?

\begin{tabular}{|c|l|c|}
\hline NO & \multicolumn{1}{|c|}{ INDIKATOR PERTANYAAN } & YA/TIDAK \\
\hline 1 & $\begin{array}{l}\text { Apakah Lokasi lapas berdekatan dengan lokasi tempat } \\
\text { tinggal narapidana }\end{array}$ & $\begin{array}{c}\text { YA DAN } \\
\text { TIDAK }\end{array}$ \\
\hline 2 & $\begin{array}{l}\text { Apakah narapidana diperkenankan menerima kunjungan } \\
\text { sesuai jadwal yang dizinkan }\end{array}$ & YA \\
\hline 3 & Apakah dikenakan Iuran untuk kunjungan & TIDAK \\
\hline 4 & $\begin{array}{l}\text { Apakah narapidana dibolehkan menerima kiriman dari } \\
\text { orang yang berkunjung }\end{array}$ & YA \\
\hline 5 & $\begin{array}{l}\text { Apakah narapidana dizinkan menerima kunjungan dari } \\
\text { pengacara/penasehat hukum }\end{array}$ & YA \\
\hline
\end{tabular}

Dari table menjelaskan pada pertanyaan D.2 dan D.5 saja yang memang setiap narapidana menerima kunjungan sesuai jadwal dan dizinkan menerima kunjungan dari penasehat hukumnya, bahkan penasehat hukumnya tidak sesuai jadwal, tidak seperti keluarga atau orang terdekatnya yang harus berkunjung disesuaikan jadwal Lapas.

\section{e. Hak Untuk Reintegrasi Sosial}

Hak untuk reintegrasi social adalah untuk mengetahui informasi mengenai remisi, asimilasi, dan pembebasan bersyarat. Hal demikian memudahkan setiap narapidana akan mendaptkan informasi tersebut dan bisa digunakan sebaik mungkin, karna hal tersebut sangat diperlukan narapidana didalam lapas. Adapun pertanyaan yang dilakukan oleh peneliti kepada petugas lapas yaitu :

$\checkmark$ E.1 : Apakah tersedia unit Layanan Informasi remisi \& program reintegrasi lain?

$\checkmark$ E.2 : Apakah ada kejelasan prosedur Remisi, Asimilasi dan Pembebasan Bersyarat?

\begin{tabular}{|c|l|c|}
\hline NO & \multicolumn{1}{|c|}{ INDIKATOR PERTANYAAN } & YA/TIDAK \\
\hline 1 & $\begin{array}{l}\text { Apakah tersedia unit Layanan Informasi remisi \& } \\
\text { program reintegrasi lain }\end{array}$ & YA \\
\hline 2 & $\begin{array}{l}\text { Apakah ada kejelasan prosedur Remisi, Asimilasi dan } \\
\text { Pembebasan Bersyarat }\end{array}$ & YA \\
\hline
\end{tabular}

Dari table diatas menjelaskan pada pemenuhan hak untuk reintegrasi social pada pertanyaan tersebut dikategorikan Baik. Bahwa segala hal yang berkaitan informasi sesuai pertanyaan yang diajukan sudah membantu narapidana untuk mengetahui hak remisi bagi mereaka dan juga asimilasi serta pembebasan bersyarat. Dalam dua pertanyaan peneliti 
bahwa petugas menjelaskan secara baik tentang ketika narapidana mendapatkan remisi sampai pembebasan bersyarat.

\section{B. Bagaimana prinsip hak asasi manusia diintegrasikan ke dalam perumusan kebijakan manajemen pemasyarakatan}

Peran lembaga pemasyarakatan sebagai wakil Negara, sangatlah penting dalam hal menghormati hak asasi Narapidana melalui pembinaan, karna sekalipun telah diusahakan berbagai hal dalam pembinaan selama menjalani pidana, namun dampak psikologis akibat pidana penjara masih masih Nampak pada Narapidana dan memerlukan penanganan serius. Narapidana sebagai bagian dari masyarakat Indonesia perlu mendapat perhatian yang sungguh-sungguh dari berbagai lapisan masyarakat agar para narapidana itu dapat menikmati hidup bermasyarakatyang tenteram. ${ }^{13}$

Peran Lembaga Pemasyarakatan sebagai Pembina narapidana mempunyai tugas memberi pengertian kepada Narapidana tersebut mengenai norma-norma kehidupan dan melibatkan mereka dalam kegiatan-kegiatan social yang dapat menumbuhkan rasa percaya diri dalam kehidupan bermasyarakat. Hal ini bertujuan agar Narapidana itu sanggup hidup mandiri. Narapidana itu harus mempunyai daya tahan, dalam arti bahwa Narapidana ituharus mampu hidup bersaing dengan masyarakat tanpa melakukan kejahatan lagi.

Pembinaan yang dilaksanakan terhadap narapidana disesuaikan dengan asas-asas yang terkandung dalam pancasila, Undang-undang dasar 1945 dan standard Minimun rules (SMR) yang tercermin dalam 10 Prinsip Pemasyarakatan. Pemasyarakatan merupakan bagian akhir dari system pemidanaan dalam tata peradilan pidana adalah bagian integral dari tata peradilan terpadu (integral Justice System). Dengan demikian, Pemasyarakatan baik ditinjau dari system kelembagaan, cara pembinaan dan petugas pemasyarakatan, merupakan bagian yang terpisahkan dari satu rangkaian proses penegakan hukum dengan memperhatikan tegaknya hak asasi manusia (HAM).

Indikator dan descriptor keberhasilan pembinaan dan pembimbingan dalam setiap tahapan didasarkan dari hasil evaluasi, hasil kegaiatan yang dilakukan oleh tim pengamat pemasyarakatan.Evaluasi ini juga dirangkaiakn dalam rangka pengalihan tahapan pembinaan, karna secara normative, pengalihan tahapan pembinaan dari satu tahap ke tahap lain ditetapkan melalui sidang tim pengamat pemasyarakatan berdasarkan data dari Pembina pemasyarakatan, Pengaman Pemasyarakatan Pembimbing Kemasyarakatan, dan Wali Narapidana. Bagi narapidana yang melakukan tindak pidana narkotika dan prekursor narkotika serta psikotropika (dijatuhi hukuman paling singkat 5 (lima) tahun), terorisme, korupsi, kejahatan terhadap keamanan negara, kejahatan hak asasi manusia yang berat dan kejahatan transnasional terorganisasi lainnya harus telah memenuhi syarat, yaitu: 1) bersedia bekerjasama dengan penegak hukum untuk membantu membongkar tindak pidana yang dilakukannya; 2) telah menjalani masa pidana paling singkat $2 / 3$ (dua per tiga) atau masa pidana paling sedikit 9 (sembilan) bulan; 3) telah menjalani Asimilasi paling sedikit $1 / 2$ (satu per dua) dari sisa masa pidana yang wajib dijalani; bagi narapidana tindak pidana terorisme telah menunjukkan kesadaran dan penyesalan atas kesalahan yang menyebabkan dijatuhi pidana dan menyatakan ikrar: bagi narapidana yang melakukan tindak pidana narkotika dan prekursor narkotika serta psikotropika, kejahatan terhadap keamanan negara, kejahatan hak asasi manusia yang berat dan kejahatan transnasional terorganisasi lainnya bersedia bekerjasama dengan penegak hukum untuk menjadi Justice Collaborator. Sementara untuk narapidana korupsi harus bersedia menjadi Justice Collaborator dan

${ }^{13}$ Samosir, 1992: 70 
membayar lunas dan uang pengganti sesuai keputusan pengadilan (Peraturan Menteri Hukum dan Hak Asasi Manusia Nomor 21 Tahun 2013 tentang Syarat dan tata Cara Pemberian Remisi, Asimilasi, Cuti Mengunjungi Keluarga (CMK), Pembebasan bersyarat (PB), Cuti Menjelang Bebas (CMB) dan Cuti Bersyarat (CB)).

Kewajiban Negara Untuk melindungi HAM warganegaranya menuntut bahwa adanya aksi dari negara yang bersifat postif yang ditujukan untuk menghindari terjadinya pelanggaran HAM oleh orang sebagai pribadi. Dalam konteks ini, negara mempunyai kewajiban untuk mencegah terjadinya konflik HAM antara manusia secara Individu atau dengan kata lain mencegah terjadinya konflik HAM secara Horizontal. Perlindungan Hukum narapidana dapat diartikan sebagai Upaya perlindungan hokum terhadap berbagai kebebasan dan hak asasi narapidana serta sebagai kepentingan yang berhubungan dengan kesejahtraan narapidana. ${ }^{14}$ Perlindungan Hukum atas hak-hal Narapidana di Indonesia sebenarnya telah diatur dalam Undang-undang No 39 tahun 1999 tentang Hak Asasi Manusia dan UndangUndang Nomor 12 Tahun 1995 Tentang Pemasyarakatan. Tindak pidana yang kerapkali menimpa Narapidana didalam Lembaga Pemasyarakatan adalah tindak pidana yang melibatkan unsur-unsur kekerasan didalamnya, baik yang dilakukan oleh sesama Narapidana maupun oleh Petugas Lapas. ${ }^{15}$

Pembinaan Narapidana mengandung makna memperlakukan seseorang yang berstatus Narapidana untuk dibangun agar bangkit menjadi seseorang yang baik. Atas dasar pengertian pembinaan yang demikian itu sasaran yang perlu dibina adalah pribadi dan budi pekerti Narapidana, yang didorong untuk membangkitkan rasa harga diri pada diri sendiri dan orang lain, serta mengembangkan rasa tanggung jawab untuk menyesuaikan diri dengan kehidupan yang tentram dan sejahtra dalam masyarakat, dan selanjutnya berpotensi luhur dan bermoral tinggi ${ }^{16}$. Pembinaan Narapidana dengan pendekatan kekeluargaan dapat meredakan ketegangan yang ada ketika Narapidana merasa hak-haknya tidak terpenuhi. Beberapa Narapidana dari berbagai lembaga pemasyarakatan tidak sungkan untuk mengambil sikap apabila hak-hak mereka tidak terpenuhi. Dengan demikian pemibanaan yang ada masih belum memberikan kesadaran sepebuhnya pada narapidana sehingga Lembaga Pemasyarakatan tetap harus menekankan bentuk program yang ada dalam Progressive Treatment Program. Disamping itu, pihak lembaga pemasyarakatan tetap mengedepankan sikap lunak dan waspada dalam membina Narapidana, sehingga mengimbangi sikap pamrih dari beberapa Narapidana yang keliru memahami berkelakuan dan bersifat baik hanya karna untuk memperoleh hak-haknya. Perlu ada pelurusan pemahaman dan perlu dijadikan perhatian kembali dengan menumpuk kesadaran diri bahwa berbuat baik tidak selalu diikuti dengan diberikannya hadiah berupa pengurangan masa pidana. Peningkatan pembinaan mental dan spiritual serta moralitas masih menajdi modal utama dalam pembekalan bagi Narapidana.

Kerjasama dengan aparat penegak hukum dan beberapa instansi terkait dalam mengatasi permasalahan di Lembaga Pemasyarakatan sangat membantu penerapan hak-hak narapidana, baik pembangunan lembaga pemasyarakatan baru, pemindahan Narapidana ke Lembaga Pemasyarakatan yang lebih sedikit penghuninya maupun mempercepat pembebasan Narapidana melalui pemenuhan hak-hak Narapidana.

\footnotetext{
${ }^{14}$ Arief, 1998: 155

15 Jaya, $1975: 36$ )

${ }^{16}$ Purnomo, 1986: 187
} 


\section{PENUTUP}

Program reintegrasi sosial atau yang lebih dikenal dengan layanan pemberianRemisi, Asimilasi, CMK, PB, CMB dan CB bertujuan untuk mengembalikan Warga Binaan Pemasyarakatan kembali bersosialisasi di tengah-tengah masyarakat sebagai seorang yang pernah terkena masalah hokum tanpa harus memberikan stigma negative terhadap perbuatan atau kesalahan yang telah mereka buat dengan pembinaan yang mereka dapatkan di lapas. Terdapat beberapa persyaratan yang diatur dalam peraturan pemerintah yang cenderung tidak harmonis dengan semangat dari Undang-undang sehingga dapat menunda atau meniadakan hak-hak tertentu untuk jangka waktu tertentu sesuai dengan peraturan perundang-undangan yang berlaku.

Pelaksanaan pemberian Hak-hak narapidana di Lembaga Pemasyarakatan masih mengalami hambatan terkait dengan prinsip Hak Asasi Manusia dimana masih adanya ketidak pahaman antar aparat penegak Hukum mengenai pengertian justice collaborator yang seharusnya sudah ditetapkan ketika pelaku pelaku belum masuk ke Lembaga Pemasyarakatan dan Lembaga Pemasyarakatan telah berupaya maksimal dalam memberikan Hak-hak Narapidana sesuai prosedur.

\section{DAFTAR PUSTAKA}

Adi Sujatno, Sistem Pemasyarakatan Indonesia Membangun Manusia Indonesia,

Dirjen Pemasyarakatan Departemen Kehakiman dan HAM RI, Jakarta, 2004.

Bambang Purnomo, Pelaksanaan Pidana Penjara dengan Sistem Pemasyarakatan, Liberty, Yogyakarta, 1986.

Barda Nawawi Arief, Kebijakan Legislatif Dalam Penanggulangan Kejahatan Dengan Pidana Penjara, Semarang, CV.Ananta, 1994.

Bunga Rampai Kebijakan hukum Pidana, Bandung, Citra Aditya Bhakti, 1996.

Bayu Suryaningrat, Perumusan Kebijaksanaan dan Koordinasi Pembangunan di Indonesia, Bina Aksara, Jakarta.

Daniel S Lev, Hukum dan Politik: Kesinambungan dan Perubahan, Jakarta, LP3ES.

G. Peter Hoefnagels, The Other Side of Criminology, Hollang: Kluwer Deventer. 1973.

kamus Besar Bahasa Indonesia, Balai Pustaka, Jakarta, 1990.

Kholibun Andaya, Esensi Keadilan Dalam Masyarakat, Universal, Medan, 1999.

Lawrence M. Friedman, American law: An Invaluable guide to the many faces of the law, and how it effects our daily lives, New York: W.W. Nonton \& Company, 1984.

\section{Perundang-undangan}

Undang-Undang Dasar Negara Republik Indonesia Tahun 1945. Undang-undang Republik Indonesia Nomor 12 Tahun 1995 tentang Pemasyarakatan.

Undang-undang Republik Indonesia Nomor 39 Tahun 1999 tentang Hak Asasi Manusia. Undang-undang Republik Indonesia Nomor 12 Tahun 2005 Tentang Pengesahan International Covenant on Civil and Political Rights (Kovenan Internasional Tentang Hak-Hak Sipil Dan Politik). 
Peraturan Menteri Hukum dan Hak Asasi Manusia Nomor 21 Tahun 2013 tentang Syarat dan Tata Cara

Pemberian Remisi, Asimilasi, Cuti Mengunjungi Keluarga (CMK), Pembebasan Bersyarat (PB), Cuti Menjelang Bebas (CMB) dan Cuti Bersyarat (CB).

Surat Edaran Nomor M.HH- 13.PK.01.05.06 Tahun 2014 tentang Pelaksanaan Peraturan Pemerintah Nomor 99 Tahun 2012 tentang Perubahan Kedua atas Peraturan Pemerintah Nomor 32 Tahun 1999 Tentang Syarat dan Tata Cara Pelaksanaan Hak Warga Binaan Pemasyarakatan. 